\title{
ANALISIS PEMANFAATAN JEMBATAN GARAM KCI DAN NaCI TERHADAP LAJU KOROSI ELEKTRODA Zn PADA SEL VOLTA MENGGUNAKAN AIR LAUT SEBAGAI ELEKTROLIT
}

\author{
Gurum Ahmad Pauzi ${ }^{\text {la, }}$ Arie Anjarwati ${ }^{1 \mathrm{~b}}$, Ahmad Saudi Samosir ${ }^{2}$, Sri Ratna Sulistiyanti ${ }^{2}$, Wasinton \\ Simanjuntak $^{3}$ \\ (1)Jurusan Fisika, FMIPA, Universitas Lampung, Bandar Lampung, 35145; \\ (2)Jurusan Teknik Elektro, FT, Universitas Lampung, Bandar Lampung, 35145 \\ ${ }^{(3)}$ Jurusan Kimia, FMIPA, Universitas Lampung, Bandar Lampung, 35145 \\ a gurum@fmipa.unila.ac.id ;b arieanjarwati.24@gmail.com
}

Artikel Info
Diterima
tanggal
12.09 .2019
Disetujui
publikasi
tanggal
31.10.2019
Kata kunci:
Cu, jembatan
garam, LED, sel
volta

\section{ABSTRACT}

This research was conducted to analyze the effect of salt bridges on the corrosion rate of Zn electrodes on electrochemical cells. Pairs of $\mathrm{Cu}(\mathrm{Ag})-\mathrm{Zn}$ electrodes are used to produce voltage and current in cells with seawater electrolytes. The salt bridge variation uses agar dissolved with $0.1 \mathrm{~mol}$ of $\mathrm{NaCl}, 0.1 \mathrm{~mol}$ of $\mathrm{KCl}, 1 \mathrm{~mol}$ of $\mathrm{NaCl}$, and $1 \mathrm{~mol}$ of $\mathrm{KCl}$. Voltaic cells consist of 20 cells arranged in series, each cell filled with $\pm 300 \mathrm{ml}$ of seawater. Voltaic cells are connected to a 3 watt 12 volt LED load for one day, and 30 days. The results showed that the $1 \mathrm{~mol} \mathrm{NaCl}$ salt bridge produced higher electrical characteristics and a higher corrosion rate to the Zn electrode.

\section{PENDAHULUAN}

Korosi adalah proses alami degradasi atau penghancuran suatu bahan atau logam yang terjadi ketika bereaksi dengan lingkungannya. Itu bisa terlihat atau tidak terlihat (Kruger and Bagum, 2016). Karena semua logam dan paduannya umumnya terkorosi, maka korosi pada mobil, perangkat mikroelektronika, berbagai industri minyak dan kimia, kano, sekam kapal, logam yang terpapar air laut, jembatan, jalan raya, dan saluran drainase tidak dapat dihindari (Roberge, 2012). Berbagai metode untuk mencegah atau menghambat laju korosi. Metodemetode ini biasanya meliputi: Penggunaan paduan sebagai pengganti logam murni, pelapisan 
logam (organik atau anorganik), peningkatan desain logam (menghindari tekanan berlebihan, meminimalkan lekukan), perlindungan elektrokimia (perlindungan anodik (Kamalia dkk, 2018), penurunan suhu, mengurangi kecepatan cairan, menghilangkan oksigen dari lingkungan, menurunkan konsentrasi larutan, menggunakan penghambat korosi) dan lain-lain (Çek, 2014, Cicek, 2017). Selain korosi alami, terdapat pula korosi galvanik yaitu korosi yang terjadi apabila dua logam yang berbeda potensial berada dalam lingkungan elektrolit, tidak dihubungkan, dan menimbulkan aliran electron atau listrik diantara kedua logam (Bardar, 2003).

Sel volta atau sel galvanik adalah sumber tegangan yang terdiri dari dua buah elektroda yang memiliki beda deret potensial dalam suatu larutan elektrolit. Pasangan elektroda $\mathrm{Cu}-\mathrm{Zn}$ menghasilkan tegangan listrik yang lebih tinggi dibandingkan dengan pasangan elektroda C$\mathrm{Zn}$, dan $\mathrm{Cu}-\mathrm{Al}$ (Pauzi dkk, 2016). Dalam penelitian ini digunakan pasangan elektroda $\mathrm{Cu}(\mathrm{Ag})-\mathrm{Zn}$, dimana pemanfaatan Ag dilakukan untuk mengurangi korosi pada permukaan $\mathrm{Cu}$. Elektroda $\mathrm{Cu}$ dilindungi dengan cara melapisinya dengan logam Ag menggunakan proses electroplating (Pauzi dkk, 2018a). Hasil penelitian menunjukkan bahwa $\mathrm{Cu}(\mathrm{Ag})$ lebih tahan terhadap korosi oleh air laut dengan laju korosi 5 kali lebih rendah dibandingkan $\mathrm{Cu}$. Pasangan elektroda $\mathrm{Cu}(\mathrm{Ag})-\mathrm{Zn}$ menghasilkan nilai karakteristik elektrik yang lebih besar dan stabil dibandingkan Cu-Zn (Pauzi dkk, 2018b). Elektroda yang berfungsi sebagai anoda adalah elektroda yang mempunyai potensial korosi lebih negative sehingga anoda cenderung bersifat korosif (Winston, 2008). Laju korosi pada sel galvanik elektroda anodik Zn mengalami korosi lebih tinggi tinggi dibandingkan elektroda Katodik. Sehingga untuk mengatasi terjadinya korosi maka digunakannya jembatan garam. Jembatan garam berfungsi untuk menyeimbangkan elektrolit dengan memberi ion positif atau negatif (Badea et. al, 2007).

\section{METODE}

\section{Alat dan Bahan}

Alat yang digunakan dalam penelitian ini adalah lampu LED DC 3 watt 12 volt, media tempat elektrolit berbentuk silender diameter $6 \mathrm{~cm}$ tinggi $12 \mathrm{~cm}(300 \mathrm{ml})$, timbangan digital TL-series (0,001 gr). Bahan yang digunakan adalah agar-agar, $\mathrm{NaCl}$ 0,1 mol, $\mathrm{NaCl} 1 \mathrm{~mol}$, $\mathrm{KCl}$ 0,1 mol, KCL 1 mol, aquades, serabut $\mathrm{Cu}$ dielektroplating dengan $\mathrm{Ag}(\mathrm{Cu}(\mathrm{Ag}))$ sepanjang $2 \mathrm{~m}$, plat $\mathrm{Zn} 3,5 \times 10 \mathrm{~cm}$ dan Air laut yang telah disaring. 


\section{Prosedur}

Pada tahap pertama; dilakukan perancangan dan pembuatan sistem sel volta yang tersusun dari 20 sel dalam wadah tertutup. Elektroda yang digunakan berisi pasangan $\mathrm{Cu}(\mathrm{Ag})-\mathrm{Zn}$ dalam satu sel. Jembatan garam yang digunakan terbuat dari agar-agar di campur larutan $\mathrm{NaCl}$ 0,1 mol pada percobaan pertama, $\mathrm{KCl}$ 0,1 mol untuk percobaan kedua, $\mathrm{NaCl} 1$ mol dan KCL 1 mol untuk percobaan ketiga dan keempat. Sebelum elektroda Zn dimasukkan ke dalam sel volta, terlebih dahulu dilakukan penimbangan massa Zn untuk mendapatkan massa awal $\left(m_{0}\right)$. Desain sel volta seperti terlihat pada Gambar 1.

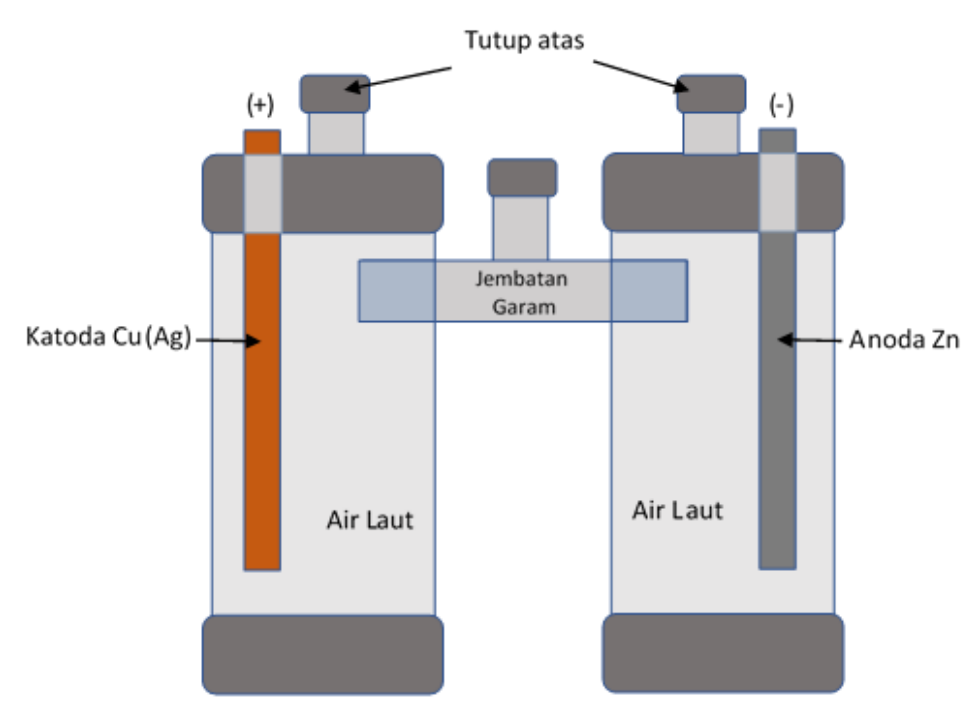

Gambar 1. Desain satu sel volta dan jembatan garam

Pada tahap kedua; menghubungkan tiap sel secara seri sebanyak 20 sel, kemudian dilakukan pengujian dengan menghubungkan dengan hambatan LED DC 3 watt 12 volt selama satu hari (24 jam) untuk tiap konsentrasi jembatan garam. Pada tahap ketiga; setelah 24 jam dilakukan penimbangan elektroda $\mathrm{Zn}$ untuk mendapatkan massa akhir $\left(m_{1}\right)$ menggunakan alat ukur berupa timbangan digital TL-series $(0,001 \mathrm{gr})$. Data perhitungan yang diambil berupa laju korosi yang dihitung dengan metode kehilangan massa (pers. 1). Pengulangan diambil dari tiga sampel elektroda $\mathrm{Zn}$ yang diambil secara random.

$$
r=\frac{K m}{\rho A T}
$$

dengan:

$$
\begin{aligned}
& r=\text { Laju korosi }(\mathrm{mm} / \mathrm{hari}) ; \\
& K=\text { Konstanta }(8,76 \times 104) ;
\end{aligned}
$$




$$
\begin{aligned}
& m=m_{0}-m_{1}=\text { massa awal }- \text { massa akhir }(\mathrm{gr}) ; \\
& \rho=\text { Densitas }\left(\mathrm{gr} / \mathrm{cm}^{3}\right) ; \\
& A=\text { Luas permukaan }\left(\mathrm{cm}^{2}\right) ; \\
& T=\text { Waktu (jam). }
\end{aligned}
$$

\section{HASIL DAN PEMBAHASAN}

\section{Analisis Laju Korosi Elektroda Zn}

Hasil perhitungan laju korosi elektroda $\mathrm{Zn}$ pada sel volta menggunakan jembatan garam $\mathrm{NaCl}$ dan $\mathrm{KCl}$ yang berbeda konsentrasi dapat dilihat pada Tabel 1, 2, 3, dan 4.

Tabel 1. Laju korosi elektroda Zn setelah digunakan sebagai sel volta selama 1 hari

\begin{tabular}{ccccc}
\hline & \multicolumn{4}{c}{ Laju korosi elektroda Zn (mm/year) } \\
\cline { 2 - 5 } Elektroda & NaCl 0,1 mol & NaCl 1 mol & KCl 0,1 mol & KCl 1 mol \\
\hline 1 & 0,088 & 0,365 & $-0,073$ & $-0,365$ \\
2 & 0,029 & 0,058 & $-6,091$ & $-0,394$ \\
3 & 0,088 & 0,058 & $-6,646$ & $-0,190$ \\
\hline Rata-rata & 0,068 & 0,160 & $-4,27$ & $-0,316$ \\
\hline
\end{tabular}

Pada Tabel 1, laju korosi Zn pada sel yang menggunakan jembatan Garam $\mathrm{NaCl}$ cenderung lebih besar dibandingkan dengan jembatan garam menggunakan $\mathrm{KCl}$, Pada $\mathrm{KCl}$, setelah dilakukan pengukuran massa dan perhitungan laju korosi pada Zn, ternyata menghasilkan nilai negatif ( $\mathrm{KCl}$ 0,1 mol dan 1 mol masing-masing -4,27 dan -3,16 mm/year), Hal ini disebabkan massa akhir setelah penimbangan tidak berkurang, dan terdapat massa tambahan disebabkan munculnya endapan berupa lapisan membran pada permukaan $\mathrm{Zn}$, Endapan tersebut sebagai akibat adanya mineral atau senyawa organik atau anorganik yang ikut terlarut dari dalam air laut secara alami (Cruz et al, 2017), Laju korosi pada Zn dengan jembatan garam $\mathrm{NaCl}$ menunjukkan nilai positif, meskipun nilai hasil perhitungan ini kecil dengan rata-rata 0,068 mm/year untuk $\mathrm{NaCl} 0,1 \mathrm{~mol}$ dan $0,160 \mathrm{~mm} /$ year untuk konsentrasi 1 mol, Hal ini disebabkan larutan elektrolit yang digunakan adalah air laut dengan $\mathrm{NaCl}$ sebagai senyawa terlarut sedangkan jembatan garam sendiri adalah $\mathrm{NaCl}$, Hal ini menyebabkan elektron lebih mudah untuk berpindah dari satu kompartemen (bagian) ke kompartemen lainnya (Arizal dkk, 2017 dan Haman dkk,, 1998), Berikut ini adalah gambar 
kondisi elektroda $\mathrm{Zn}$ pada berbagai konsentrasi jembatan garam selama 1 hari digunakan sebagai sel volta,

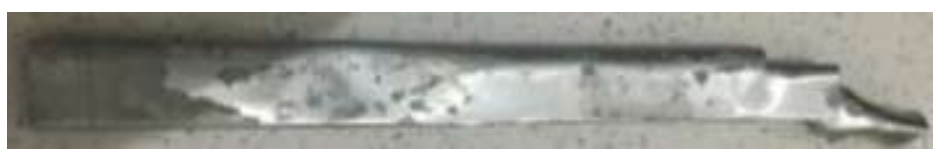

a.

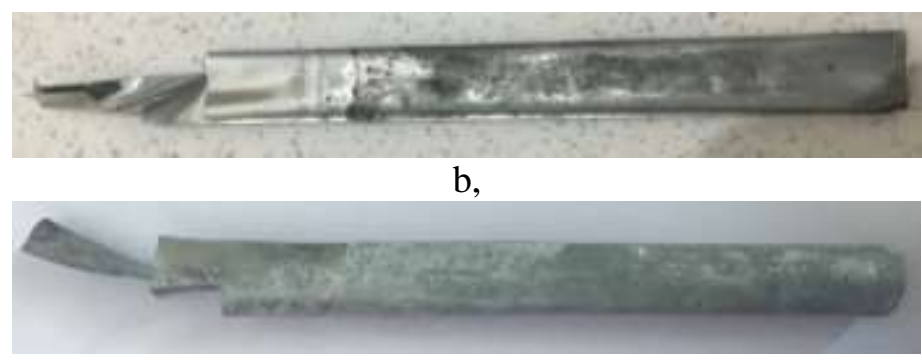

$\mathrm{c}$,

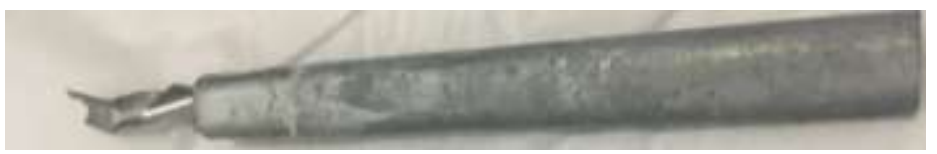

$\mathrm{d}$,

Gambar 2, Elektroda Zn setelah penggunaan selama satu hari sebagai sel volta a) jembatan garam $0,1 \mathrm{~mol} \mathrm{KCl}$, b) Dengan jembatan garam $\mathrm{NaCl} 0,1 \mathrm{~mol} \mathrm{c})$, dengan jembatan garam $1 \mathrm{~mol} \mathrm{KCl,} \mathrm{d),} \mathrm{dengan} \mathrm{jembatan} \mathrm{garam} 1 \mathrm{~mol} \mathrm{NaCl}$,

Dari Gambar 2 di atas terlihat bahwa kondisi Zn dengan konsentrasi yang sama menunjukkan korosi lebih terlihat pada jembatan garam $\mathrm{NaCl}$ dibandingkan dengan $\mathrm{KCl}$,

\section{Analisis Arus dan Tegangan pada sel volta dengan variasi jembatan garam}

Pengukuran besarnya tegangan dan arus yang dihasilkan oleh sel volta adalah seperti pada tabel 2 dan tabel 3, Beban LED 3 watt 12 volt di hubungkan pada sel volta, Pengukuran merupakan hasil rata-rata pengamatan arus dan tegangan tiap sel selama 24 jam dengan pengambilan data setiap 1 jam,

Tabel 2, Tegangan sel volta dengan berbagai jembatan garam selama 24 jam

\begin{tabular}{lcccc}
\hline & \multicolumn{4}{c}{ Tegangan sel (Volt) } \\
\cline { 2 - 5 } Jenis Jembatan Garam & NaCl 0,1 mol & NaCl 1 mol & KCl 0,1 mol & KCl 1 mol \\
\hline Tegangan rata-rata sel volta & 12,281 & 15,367 & 8,221 & 12,142 \\
Rata-rata tiap sel & 0,614 & 0,768 & 0,411 & 0,607 \\
\hline
\end{tabular}

Hasil pengukuran tegangan di atas merupakan pengukuran saat beban LED 3 watt 12 volt di lepaskan (tanpa beban), Tabel 2 menunjukkan bahwa tegangan rata-rata pada sel volta 
dengan jembatan garam $\mathrm{NaCl}$ pada konsentrasi 0,1 mol dan 1 mol selalu lebih besar dari sel volta dengan jembatan garam $\mathrm{KCl}$ pada konsentrasi yang sama, Pada tegangan rata-rata setiap sel pada konsentrasi jembatan yang sama tidak terlalu terlihat selisih tegangan yang cukup jauh, Namun tinjauan dengan hanya mengamati variable tegangan tidak cukup lengkap tanpa melihat besarnya arus yang dihasilkan oleh sumber tegangan (sel volta), Berikut ini adalah pengukuran arus yang mengalir pada beban seperti terlihat pada Tabel 3,

Tabel 3, Pengukuran arus sel volta dengan berbagai jembatan garam selama 24 jam

\begin{tabular}{lcccc}
\hline \multirow{2}{*}{ Elektroda } & \multicolumn{4}{c}{ Arus sel (mA) } \\
\cline { 2 - 5 } & $\mathrm{NaCl} \mathrm{0,1} \mathrm{mol}$ & $\mathrm{NaCl} 1 \mathrm{~mol}$ & $\mathrm{KCl} \mathrm{0,1} \mathrm{mol}$ & $\mathrm{KCl} \mathrm{1} \mathrm{mol}$ \\
\hline Rata-rata 24 jam sel volta & 0,216 & 1,842 & 0,022 & 0,530 \\
Rata-rata tiap 1 sel & 0,010 & 0,092 & 0,011 & 0,027 \\
\hline
\end{tabular}

Pada Tabel 3, meskipun selisih tegangan antara $\mathrm{NaCl}$ dan $\mathrm{KCl}$ pada konsentrasi yang sama tidak besar namun arus yang dihasilkan pada konsentrasi yang sama berbeda cukup jauh, Hal ini menunjukkan bahwa terdapat hambatan dalam yang cukup tinggi pada jembatan garam $\mathrm{KCl}$, konduktifitas yang kecil sangat berpengaruh pada besarnya arus dan daya yang dihasilkan oleh sel volta,

Pengamatan menunjukkan bahwa terdapat korelasi laju korosi (Tabel 1) terjadi dengan semakin besarnya arus yang dihasilkan oleh sel volta (tabel 3), Hal ini disebabkan apabila dua unsur di celupkan dalam larutan elektrolit dengan sumber arus maka yang mengalami korosi adalah material yang lebih anodik (Tretheway, 1991), Arus yang mengalir melewati elektrolit $\mathrm{NaCl}$ menghasilkan performa nilai yang lebih optimum sehingg sehingga terjadi korosi pada anoda (Ulfia dkk, 2015), Hal ini menunjukkan bawah laju korosi sebanding dengan besarnya arus dan tegangan yang dihasilkan oleh sel volta, Tabel 2 dan tabel 3 menunjukkan tegangan dan arus yang dihasilkan oleh jembatan garam $\mathrm{NaCl}$ pada konsentrasi $1 \mathrm{~mol}$ rata rata selama 24 jam menghasilkan nilai terbesar nilai, hal ini sebanding dengan laju korosi pada anoda $\mathrm{Zn}$,

Tabel 4, Laju korosi elektroda $\mathrm{Zn}$ dengan jembatan garam $\mathrm{NaCl} 1$ mol selama 30 hari

\begin{tabular}{cc}
\hline Elektrode & Laju korosi elektroda $\mathbf{Z n}(\mathbf{m m} /$ year $)$ \\
\hline 1 & 0,420 \\
2 & 0,338 \\
3 & 0,349 \\
\hline Rata-rata & 0,369 \\
\hline
\end{tabular}


Pengamatan laju korosi Zn selanjutnya difokuskan pada sel volta dengan jembatan $\mathrm{NaCl} 1$ mol selama 30 hari, Pengamatan ini lakukan dengan tetap memberikan beban pada LED 3 watt 12 volt, Seperti ditunjukkan pada Tabel 4, Data massa Zn diambil secara random dari 20 sel volta, Adapun kondisi elektroda selama setelah digunakan selama 30 hari sebagai sel volta dengan jembatan garam $\mathrm{NaCl}$ seperti pada Gambar 3,

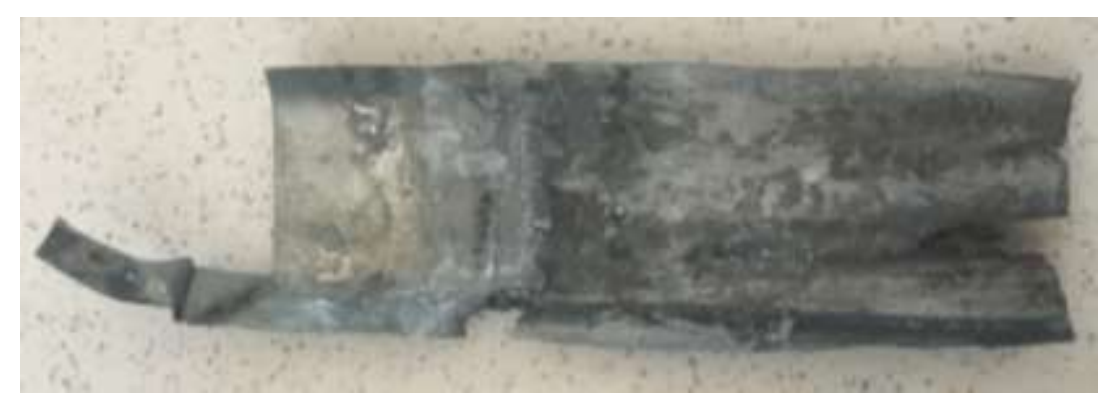

Gambar 3, Elektroda Zn setelah 30 hari digunakan sebagai sel volta dengan jembatan garam $\mathrm{NaCl} 1 \mathrm{~mol}$

Gambar 3 terlihat bahwa permukaan elektroda Zn sudah terjadi degradasi akibat terjadinya korosi tetapi kondisi elektroda masih mampu untuk digunakan pada penggunaan lebih lanjut, Pada Tabel 1, hari pertama rata-rata belum terjadi korosi yang signifikan, namun pada hari ke 30 terjadi peningkatan laju korosi 0,369 mm/years, Semakin lama elektroda $\mathrm{Zn}$ akan mengalami korosi terus menerus seiring bertambahnya waktu pakai elektroda sampai elektroda Zn habis (Pauzi dkk, 2018), Hal ini disebabkan karena Zn mengalami pelepasan elektron terus menerus dalam waktu yang lama, dan elektrolit air laut mengalami penambahan tingkat keasamaan $\mathrm{pH}$ elektrolit air laut (Wisudyaningsih dkk, 2014), Logam Zn akan terurai didalam elektrolit yang juga mengandung ion-ion $\mathrm{Zn}$, Ion-ion $\left(\mathrm{Zn}^{2+}\right)$ akan terbawa kemudian mengendap pada permukaan Katoda dan berubah menjadi atom-atom seng, Pada kondisi ini terjadi reaksi reduksi ion seng menjadi logam seng sebagai berikut (Ansari dkk, 2017):

$$
\begin{gathered}
\mathrm{ZnCl}_{2} \rightleftharpoons \mathrm{Zn}^{2+}+2 \mathrm{Cl}^{-} \\
\mathrm{H}_{2} \mathrm{O} \rightleftharpoons \mathrm{H}^{+}+\mathrm{OH}^{-} \\
\mathrm{Zn}^{+2} \rightleftharpoons 2 \mathrm{e}+\mathrm{Zn}
\end{gathered}
$$

Peristiwa ini mengakibatkan terbentuknya suatu lapisan garam sehingga jika menempel pada permukaan katoda akan menimbulkan ganguan terbentuknya lapisan struktur mikro, Variasi korosi $\mathrm{Zn}$ dengan $\mathrm{pH}$ berkaitan dengan arus katodik, Laju korosi galvanik turun pada kisaran 
pH 7 hingga 10, Sehingga diprediksi kisaran pH ini tidak menyebabkan korosi berjalan efektif (Thomas et, al, 2012),

Pengendalian laju transfer elektron pada $\mathrm{Zn}$ dapat dilakukan untuk mengurangi laju korosi (Prabhu et, al, 2012), Adanya jembatan garam akan mengurangi laju transfer elektron antar kompartemen secara langsung, Jembatan garam berfungsi untuk menyeimbangkan elektrolit pada tiap kompartemen dengan memberi ion positif atau negatif,

\section{KESIMPULAN}

Pemanfaatan jembatan garam berpengaruh pada laju korosi pada elektroda anodik, Pada penelitian ini, laju korosi pada $\mathrm{Zn}$ dipengaruhi oleh tingkat konduktifitas jembatan garam, Pada sel volta dengan elektrolit air laut, jembatan garam $\mathrm{NaCl}$ menghasilkan arus dan tegangan yang lebih besar dibandingkan $\mathrm{KCl}$, sekaligus meningkatkan laju korosi pada $\mathrm{Zn}$,

\section{UCAPAN TERIMA KASIH}

Peneliti mengucapkan terimakasih kepada LPPM Universitas Lampung atas bantuan dana hibah penelitian dan hibah prototype, Peneliti juga mengucapkan terimakasih kepada Laboratorium Elektronika Dasar Jurusan Fisika, Fisika Inti, dan Eksperimen atas Izin tempat Penelitian,

\section{DAFTAR PUSTAKA}

Ansari, I,, Indra, B, W, Nurohmahwati, F, dan Zakaria, I,, 2017, Pengaruh Waktu dan Luas Permukaan terhadap Ketebalan Produk Pada Elektroplating ACID ZINC, Jurnal Teknik kimia, Universitas Pamulung, Tanggerang Selatan, Vol, 1, No, 1,

Arizal F,, Hasbi M, dan Kadir A, 2017, Pengaruh Kadar Garam terhadap daya yang dihasilkan Pembangkit Listrik Tenaga Air Garam sebagai Energi Alternatif Terbarukan, Jurnal Ilmiah Teknik Mesin, Vol, 2, No,2,

Badea, G,E, I,Maior,, A,Cojocaru,, I,Pantea,, and T,Badea,, 2007, Seawater Electrolysis for Hydrogen Production, Revue Roumaine de Chimie, 54(1), pp 55-61,

Bardal, Einar, 2003, “Corrosion and Protection", springer, Norway,

Cek, N, 2014, "Reduction of copper corrosion effect using vaseline", $13^{\text {th }}$ International Corrosion Symposium, Elazığ, Turkey, pp, 155-158,

Cicek, V, 2017, Corrosion Engineering and Cathodic Protection Handbook: With an Extensive Question and Answer Section, Jhon Wille \& Sons, USA, 
Cruz, O,R,, E, Ávila, E, Mejía, T, Pérez, A, Contreras, R, Galván-Martínez, 2017, In situ Corrosion Study of Copper and Copper-Alloys Exposed to Natural Seawater of the Veracruz Port (Gulf of Mexico), International Journal of Electrochemical Science, Vol, 12 pp, 3133 - 3152, doi: 10,20964/2017, 04,27,

Hamann, C,H,, Hamnett, A,, Vielstich, 1998, Electrochemistry, Wiley VCH, USA,

Kamalia, L, Pauzi, G,A, Suciyati, S,W,, 2018, “Analisis Laju Korosi Elektrode Bahan CuZn dengan Metode Sacrificial Anode Pada Sistem Energi Listrik alternatif Berbasis Air laut," Jurnal Teori dan Aplikasi Fisika, vol, 06, no 02, pp 249-255,

Kruger, J, Begum, S,, 2016, Corrosion of Metals: Overview,, Reference Module in Materials Science and Materials Engineering, Elsevier,

Pauzi, G,A, Riski, K,C, Suciyati,S,W, Junaidi, Surtono, A, Supriyanto, A,, and Warsito, 2018a, Improvement of Electrical Characteristics of Electrochemical Cells made from Sea Water Using Electroplating Method of $\mathrm{Cu}(\mathrm{Ag})-\mathrm{Zn}$ Electrode as Renewable Energy Source, Proceeding $2^{N D}$ International Conference Applied Sciences Mathematics and Informatics 2018, Bandar Lampung, Indonesia,

Pauzi, G, A, Arwaditha, R,K, Supriyanto, A, Suciyati, S,W, Surtono, A, Junaidi, Warsito, (2018b), "Desain dan Realisasi Akumulator Elektrolit Air Laut dengan Penambahan Sodium Bicarbonate (NaHCO3) sebagai Sumber Energi Alternatif," Jurnal Fisika, 8, (2), 78-8,

Pauzi, G, A,, Hudaya, E, Supriyanto, A,, Warsito, dan Surtono, A, 2016, Analisis Uji Karakteristik Elektrik Air Laut sebagai Sumber Energi Listrik Terbarukan, Prosiding Seminar Nasional Sains Matematika Informatika dan Aplikasinya IV, Vol, 4, Hal, 1-8,

Prabhu, R, A,, Venkatesha,, T,V,, and Praveen, B, M,, 2012, Electrochemical Study of the Corrosion Behavior of Zinc Surface Treated with a New Organic Chelating Inhibitor, Research Article, ISRN Metallurgy, ID 940107,

Roberge, P,R,, 2012, Handbook of Corrosion Engineering, Second ed, McGraw Hill,

Thomas, N, Birbilis, M,S, and Venkatraman, I,S,, 2012, Cole, Corrosion of Zinc as a Function of pH, CORROSION ;68(1):015009-1-015009-9,

Trethewey, K,, 1991, General Chemistry, 10th penyunt,Texas: Cengage Learning,

Ulfia N,, Samudro G, dan Sumiyati S,, 2015, Pengaruh konsentrasi Chemical Oxygen Demand (Cod) dan Larutan Garam dalam Jembatan Garam terhadap Kinerja dual Chamber Microbial Fuel Cells (Dcmfcs), Jurnal Teknik Lingkungan,

Winston, Revie R, 2008, Corrosion And Corrosion Control An Introduction To Corrosion Science And Engineering Fourth Edition, A John Wiley \& Sons, Inc,

Wisudyaningsih B,, Suwaldi,, dan Kharisa A, N,, 2014, Pengaruh pH dan Kekuatan Ionik terhadap Prol Kelarutan oksasin (Effects of $\mathrm{pH}$ and Ionic Strength on the Solubility Prole of oacin), Jurnal Ilmu Kefarmasian Indonesia, Vol, 12, No,1, 